\title{
An Analysis on the Training Strategy of Innovative Ability of Students Majoring in Visual Communication Design
}

\author{
Yongxiao Liu*, Qing Li, Yifan Zhao
}

\author{
Baoshan University, Baoshan, Yunnan, 678000 \\ *Corresponding author. Email: 314320737@qq.com
}

\begin{abstract}
In Chinese colleges and universities, visual communication major mainly provides high-quality talents for the media industry, with the focus on training students' professional skills in the teaching process and the objective of training innovative talents. In such a competitive society, students are required to have a certain innovative ability, so that they can work with ease. To strengthen the practical education reform in schools, it is necessary to combine teaching model with innovative ability and change the qualified talent training mode. The training objective of visual communication design major should highlight the students' innovative ability by combining their actual conditions and the market demand, thereby conveying high-quality talents to the society. This paper elaborates the necessity of training the inventive ability of students majoring in visual communication design and the present situation of innovative ability training of students majoring in visual communication, to propose the ways of training the innovative ability of students majoring in visual communication design, hoping to make certain contributions to the sustainable development of visual communication major in China.
\end{abstract}

Keywords: Visual communication, Student, Innovative ability, Training strategy.

\section{INTRODUCTION}

With the constantly deepened quality-oriented education in China, more and more universities have attached importance to train students' innovative ability. Among the art design majors in Chinese universities, visual communication design is a very important part, and it is an important subject for colleges and universities to cultivate design talents for the society. In the process of cultivating students majoring in visual communication design, innovative is the driving force of students' development, so students are required to produce good innovative ability, in order to adapt to the needs of social development. In addition, visual communication design emphasizes students' practical ability, which requires the major to lay equal stress on training students' innovative ability and developing their practical ability, so that students will become compound talents with higher comprehensive quality. Therefore, it is of crucial significance for the visual communication design major in colleges and universities to train students' innovative ability.

\section{NECESSITY OF TRAINING THE INNOVATIVE ABILITY OF STUDENTS MAJORING IN VISUAL COMMUNICATION DESIGN}

Among the art majors in colleges and universities, visual communication design is a discipline with strong practicality and professionalism. This major is developed from the graphic design major, and has higher requirements for students' innovative ability and aesthetic capability. Visual communication design is to design the package of target products with abundant materials such as picture and text, so that they have certain aesthetic functions. This major is closely related to daily life, and as a discipline with strong practicality, its application can be found in many aspects of people's daily life. For example, visual communication design is used to beautify products and embellish their living environment, or applied in the advertising field to make advertisements more attractive and stimulate people to consume, all of which are unconsciously influencing people. This major focuses on innovation, which means students should fully 
use their creative thinking and use different elements creatively in the learning process, and this is the value of visual communication design [1]

At present, some developed countries have made unprecedent progress in the design field, and influenced and stimulated by the cutting-edge design of developed countries, the development level of visual design in China has also been greatly improved. The visual communication design major in our country is just in its infancy. With the rapid economic development, people's aesthetics have also undergone great changes. For some products, people pay equal attention to their attraction and performance, which imposes higher requirements on design talents [2]. Hence, colleges and universities should focus on training students' innovative ability and creative ability in the daily teaching process. In this way, students can constantly meet the market demand and better adapt to their jobs in the future [3].

\section{PRESENT SITUATION OF TRAINING THE INNOVATIVE ABILITY OF STUDENTS MAJORING IN VISUAL COMMUNICATION DESIGN}

\subsection{Present situation of talent training objectives}

In China, the primary objective of cultivating visual communication talents is to meet the development needs of society and enterprises, which requires students majoring in visual communication design to develop favorable innovative ability and practical ability. As more and more Chinese colleges and universities set up the visual communication design major, there comes a series of issues in enrollment and teaching quality in the specific admission process. In consequence, the ability of fresh graduates does not match with the professional requirements of enterprises, resulting in low employment quality and employment difficulty. In addition, some colleges and universities fail to set a clear orientation for the training of talents in this major, causing confused objectives of talent training in daily teaching work, and some of them even training students still in accordance with the traditional way of training art and music majors, which lacks professionalism and pertinence, neither makes for the personalized development of students nor meets the market demand for visual design talents, and to some extent hinders the development of students' innovative and practical ability [4].

\subsection{Present situation of education}

The teaching of visual communication in China arose in the early 20th century, and its main purpose is to revitalize our national industry. After the reform and opening up, our country has achieved rapid development in the education field, and gradually formed more professional education of visual communication. Different from previous art education, visual communication education is constantly changing as the time marches on. At the present stage, many colleges and universities have set up the visual communication design major. However, because this major is just in its infancy with a narrow range of teaching methods and contents, teachers take the traditional force-feeding theory teaching as the main teaching method, and students are passively accepting knowledge in the class, which to some extent affect students' learning initiative and is not conducive to the training of students' innovative ability and the exertion of their imagination [5]. Furthermore, some colleges and universities also have a problem of emphasizing theory but neglecting practice. As a result, students' practical ability cannot be effectively trained, which affects the development of their comprehensive abilities.

As the market imposes increasingly high requirements for the innovative and practical ability of students majoring in visual communication design, many colleges and universities have optimized the major courses of visual communication design at this stage, such as incorporating some information technology, multimedia and practical teaching contents into the course teaching of this major. However, all of these are simply changes in form, without any adjustment to the course structure of this major. The traditional classroom teaching method is still in use, and the teaching content is fairly outdated, which is far from the diversified teaching required by the society for students of this major at the present stage. Moreover, students have little interest in learning in the classroom, much less train their innovative ability. This is far from meeting the social demand for visual design talents [6]. With the continuous development of information technology, many new industries have emerged, which have brough a lot of changes to people's life, and to some extent promoted the reform and adjustment of the teaching and curriculum systems in colleges and universities to better adapt to the current social trends. Especially for the visual communication design major, it is necessary for this major to keep absorbing new things and ideas to retain eternal vitality and vigor [7].

\section{WAYS TO TRAIN THE INNOVATIVE ABILITY OF STUDENTS MAJORING IN VISUAL COMMUNICATION DESIGN}

\subsection{Train students' innovative and practical ability}

In order to broaden students' imagination, effectively improve their comprehensive qualities and provide versatile talents with innovative ability for the society, it is necessary that colleges and universities make some adjustments in the curriculum design of visual 
communication design to arouse students' interest in learning and train their consciousness of innovation and ability to independently explore new knowledge. In addition, colleges and universities should adjust the objective from cultivating students' knowledge to cultivating their practical and innovative ability, so that they will not lag behind the development of the times. Moreover, colleges and universities should also design the learning courses for students based on their actual conditions and treat them as different individuals; respect their diversity and individuality, and regard them as the teaching subject in the class; guide them to experience public aesthetics from different perspectives and accept their different aesthetic ideas. In this way, their interest in learning can be fully stimulated, and they will realize the charm of visual communication design in the class and be more enthusiastic about learning the knowledge of this major.

\subsection{Cultivate students' diversified thinking paths}

In visual communication design, one of the sensory functions, namely vision, is used to experience the overall effect. In the design process, students should not handle the design or produce the works simply from one perspective. The design must be creative and innovative, which should be constructed by students with their divergent thinking. Then, what should colleges and universities do to cultivate students' innovative ideas? Colleges and universities should cultivate students' diversified thinking paths in the teaching process. Students' interests and hobbies should be combined with the teaching mode, and teachers are not allowed to forcibly incept their own ideas into students' mind, but should respect students' ideas and their personality development, thereby cultivating design talents that meet the market requirements. Moreover, students are allowed to select design concept and style based on their hobbies and interests. Teachers should not blindly belittle students' unconstrained ideas, but should guide students to expand their imagination and praise their ideas, so that they dare to think and dare to do instead of ponderously copying the teacher's ideas. It is necessary for students majoring in visual communication design to have confidence in their aesthetic capability [8].

\subsection{Encourage students to actively participate in design competitions}

Colleges and universities should encourage students to participate in various competitions, for the purpose of making gains instead of winning something, such as the acting ability according to circumstances and the training of their own skills. These competitions help students greatly improve their professional skills. Only by constantly strengthening their own inner world can the students calmly deal with any issues in their future lives.
Students majoring in visual communication design can cultivate their innovative ability by participating in more competitions. This is because students will be given different design themes in the competitions which are jointly organized by companies, and the design themes are also set by these companies. In this way, students can not only practice their skills, but also have a comprehensive understanding of the market demand for design talents. Nevertheless, neither colleges nor teachers in the major should force students to participate in design competitions. They should develop students' interest in participating in design competitions, and provide necessary guidance and psychological counseling for students in the competition, so that students can enjoy the competition. In addition, they should make students understand that the purpose of participating in competitions is not to win a prize, but to practice their skills, learn from others and improve their abilities in all aspects [9].

\subsection{Cultivate professional talents in combination with the market trend and industry trends}

In Chinese colleges and universities, the teaching content of visual communication design is generally confined to the traditional classroom teaching, and lacks the training of students' practical ability. As a result, many graduates are not engaged in the field related to their major and many of them fail to meet the social standard for professional talents. In the daily teaching process, teachers should guide students to reflect on what kind of works are innovative, what kind of works will be recognized by the market and what is the significance of visual communication design and other questions in addition to the knowledge they have learned. These questions may not be valuable for other majors, but they are of great significance to students majoring in visual communication design, because more thinking and practice is an effective way to improve their divergent thinking. Finally, teachers may organize some activities or games in course teaching and design different game themes for students, and guide students to participate in the activities, thereby improving their professional skills and helping them accumulate profound practical experience, which is of far-reaching positive significance to the training of students' autonomous learning ability and the improvement of their innovative consciousness. Moreover, some students may be confused about their work orientation after graduation and do not improve themselves in combination with the market demand. To this end, colleges and universities may solve these problems through university-enterprise cooperation. In this way, students have more opportunities to know the design industry as well as to take part-time and internship positions, so they can greatly improve their professional skills in this process. Enterprises may assign some outstanding designers to instruct students in the campus, 
or invite students to visit the enterprises, aiming to let the students see more, think more and practice more, so that students' practical and innovative ability can be rapidly improved. Besides, colleges and universities may invite some experts in the industry to give lectures in the campus to broaden students' horizons, thereby improving students' comprehensive qualities and helping them cater to the market demand for students majoring in visual communication design. Moreover, teachers in colleges and universities may carry out investigations in enterprises to fully understand the specific market requirements for the post related to visual communication design and learn more about the enterprises' operation mode and future development, so that they can well arrange the teaching content, teaching direction and teaching practice. In summary, the knowledge that students learn in school is one-sided and most of which is theoretical knowledge. However, the visual communication design major requires students to have solid practical skills in addition to theoretical knowledge, so that their creative thinking will not detach from the society. Only when teachers' teaching method caters to the market can they keep pace with the time, provide higher quality talents to the market, and accomplish teaching objectives.

\subsection{Update teaching ideas and contents and adjust teaching structure}

No matter for colleges and universities or teachers, it is necessary for them to keep pace with the times by constantly updating their education concepts in the teaching or curriculum design process, have a full understanding of new design forms and contents in the society, and add new teaching contents in combination with the development trend of new majors. For example, visual communication design often involves multiple media forms such as electronic media, auditory media and visual media, all of which have different transmission methods and then have different emphases. Therefore, teachers need to take these different forms of media into account in the teaching process, and carry out teaching with different emphases. In addition, teachers also need to carry out teaching and adjust curriculum structures according to students' actual conditions and interests, take students as the subject in the class, and stimulate their interest in learning by virtue of various new media and teaching tools, thereby creating a relaxed classroom atmosphere in which students can stimulate their innovative ability.

\section{CONCLUSIONS}

In conclusion, innovative ability is a necessary ability for students majoring in visual communication design. The ability of independent innovation and active exploration is a prerequisite for talents in all industries. Colleges and universities should cultivate students' innovative ability by carrying out university-enterprise cooperation, encouraging students to participate in competitions, adjusting curriculum structures and other ways in combination with students' actual conditions. Moreover, it is also necessary for students to realize that art design major aim at serving people, require them to enhance their aesthetics and feel the beauty from multiple perspectives, and stimulate their imagination and passion for creation. Only in this way can high-quality applied talents that meet the market demand be cultivated.

\section{ACKNOWLEDGMENTS}

About the author: Yongxiao Liu (1983-), male, native in Tengchong, Yunnan, Associate Professor, research interest of Advertising.

\section{REFERENCES}

[1] Zhenbian Zhang. Effective Training of Innovative Ability of Students Majoring in Visual Communication Design $[\mathrm{J}]$. China National Exhibition, 2019(8): 173-174.

[2] Ling Liu. Teaching Reform in Colleges and Universities Driven by Training of Innovative Ability of Students Majoring in Visual Communication Design [J]. Packaging World, 2019(6): 92-93.

[3] Xingzi Huang. On the Training of Innovative Ability of Students Majoring in Visual Communication Design [J]. The Guide of Science \& Education: Electronic Edition (Issue 1), 2019(11): 129.

[4] Yuzhou Li. Training of Innovative Ability of Students Majoring in Visual Communication Design [J]. DG Best, 2020(4): 168.

[5] Hong Chang. Teaching Reform in Colleges and Universities Driven by Training of Innovative Ability of Students Majoring in Visual Communication Design $[\mathrm{J}]$. Art Education Research, 2016(17): 146.

[6] Xuan Song. Research on the Training of Creative Thinking Ability of Students Majoring in Visual Communication in Higher Vocational and Technical Colleges [J]. Sino-Foreign Exchange Monthly, 2019, 26(14): 35 .

[7] Mingfei Ma. Discussion on the Training of Innovative Ability of Students Majoring in Visual Communication Design in the New Era [J]. Art Education Research, 2015(12): 146.

[8] Yujing Li. Research on Promoting Mechanism of Innovative and Entrepreneurship for Students Majoring in Visual Communication Design in 
Universities [J]. Journal of Chongqing Technology and Business University (Natural Science Edition), 2019, 36(6): 123-128.

[9] Hong Chang. Teaching Reform in Colleges and Universities Driven by Training of Innovative Ability of Students Majoring in Visual Communication Design [J]. Art Education Research, 2016(17): 146. 